1939 гг.), Главного совета адвокатов Польши в Варшаве (1937-1939 гг.), членом-основателем Украинского юридического общества в Чехословакии (1923 г.). В научной сфере В. Старосольский реализовал себя как член редакций юридических журналов, автор ряда юридических и социологических работ, монографий, пособий.

Ключевые слова: Владимир Старосольский, ученый, адвокат, общественный деятель.

Tyshchyk B., Novosiadlo I. Volodymyr Starosolsky - Outstanding Scholar, Lawyer, Politician. V. Starosolsky is a well-known Ukrainian social and political figure and a lawyer. He was a typical representative of the Ukrainian-Polish borderline region, coming from a mixed family. He becomes an active advocate of Ukrainians in the Ukrainian human rights movement in Western Ukraine. As a lawyer, he actively participates in the political processes of the Polish authorities against Ukrainians - members of the OUN, UVO, public figures, and politicians of different ideological orientations. V. Starosolsky tried to influence the process of constructive solution of the painful Ukrainian problem in Poland. As for UkrainianPolish relations, V. Starosolsky always believed that the best form of solving the conflict is dialogue. During his extraordinary life, V. Starosolsky held the positions of Deputy Minister of Foreign Affairs of the Ukrainian People's Republic (1919-1920), Doctor of Laws, Professor of the Ukrainian State University in Kamianets-Podilskyi (1919-1920), Ukrainian Free University in Prague (1921-1928) and the Ukrainian Academy of Economics in Podebrat (1922-1928). As a public figure and lawyer, he acted as a full member of the T. Shevchenko Scientific Society in Lviv (1923), Chairman of the Ukrainian Social Democratic Party (1937-1939), founding member of the Ukrainian Bar Association in Lviv (1909), member of the Board of the Ukrainian Lawyers Union in Lviv (1929-1939) ), the Lviv Chamber of Advocates (1928-1939), the Chief Bar Council of Poland in Warsaw (1937-1939), a founding member of the Ukrainian Law Society in Czechoslovakia (1923). V. Starosolsky also realized himself in the scientific domain as a member of editorial boards of legal journals, author of a number of legal and sociological research papers, monographs, and manuals.

Key words: Volodymyr Starosolsky, scientist, lawyer, public figure.

УДК 342.72

DOI https://doi.org/10.32782/2409-4544/2019-2/7

Ю. Турянський

\title{
Генезис прав людини у період античності
}

У статті розглядається історична парадигма зародження основ сучасного розуміння прав людини уперіод античності. Досліджено історичне становлення прав людини в стародавній Греції. Зокрема проаналізовано основні світоглядні ідеї Демокрита, Протагора, Сократа і Аристотеля. Первинне формування основних засад поняття прав людини сягає античних часів. Це поняття було тісно пов'язане з громадянством в містах Стародавній Греції і проявлялося в процесі становлення рівності жителів поліса і в можливості користуватися політичними правами. Софісти одні із перших давньо-грецьких філософів та мислителів розглядають не природу та космос як основу основ, а саме людину, яку наділяли особливим та вищим значенням у світобудові. Природне право софісти трактували досить по-різному, розділившись на дві основні течії. Спільним міркуванням було саме визнання людської природи як джерела прав. Представники егалітаристської течії притримувались думки, що всі люди є рівними, незважаючи на місце народження, сім'ю чи майнові статки. На основі філософської думки Платона відбувся перший етап розвитку ідеї гендерної рівності. За філософією Платона в державі повинна панувати справедливість, враховуючи природні відмінності та нерівності людей. Мислитель розділяв людей за їхніми особливостями, та вважав, що у державі кожен повинен займати своє місце. Аристотель своїм вченням почав становлення принципу верховенства права $\mathrm{i}$ наділяв державу особливим регулятором, який здатний забезпечити права людей. Тому античність оцінюється як перший етап зародження прав людини. Видатні особистості того періоду через

(С Туринський Ю., 2019 
філософське тлумачення заклали наріжні камені в історичному розвитку даного поняття. Основні трактати Аристотеля стали розвивати поняття громадянства та політичної участі людини у веденні громадських справ, що з еволюційними процесами стали основою першого покоління прав людини.

Ключові слова: права людини, держава, суспільство, права, свободи.

Постановка наукової проблеми та її значення. У сучасності кожна розвинута держава світу прагне високого дотримання прав людини для забезпечення найкращих умов життя для кожного індивіда. Усі правові держави декларують у своїх конституціях, що людина є основною цінністю, а дотримання іiї прав ставиться як пріоритетним завданням держави. Прагнення людини до належного

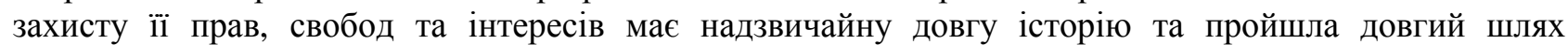
трансформацій та змін, що покликані створити умови людиноцентриського виміру для кожного. Ще із самого початку свого існування людина прагнула покращити своє життя, створити умови в яких б зберігалися іiі первісні та базові інтереси, крізь призму історичної еволюції ми вбачаємо як поступально людина визнавала, що їі життя та свобода $є$ основною цінністю як для самої неї так і для соціального буття. Історичні витоки показують як людина поступово відходила від божественного сприйняття світу та свого існування, а приділяла найбільшої уваги власне рівності та свободі, адже першочергово всі ми народжені вільними для існування у цьому світі. Що і ставало основними підваленами у формуванні сучасного сприйняття прав людини, які ми маємо сьогодні.

Аналіз досліджень цієї проблеми. Дослідження історичного генезису прав людини здійснювали такі науковці, як С. Головатий, І. Жаровська, П. Рабінович, О. Скакун, Г. Гудима та багато інших. Проте комплексного дослідження щодо розвитку історичної думки становлення прав людини досі не було проведено, тому вважаємо за необхідне дослідити дане питання.

Метою статті $€$ грунтовний аналіз зародження інституту прав людини в період античності.

Виклад основного матеріалу й обгрунтування отриманих результатів дослідження. У статті 3 Конституції України проголошено: «Людина, іiі життя і здоров'я, честь і гідність, недоторканість і безпека визначаються в Україні найвищою соціальною цінністю. Права і свободи людини та їх гарантії визначають зміст і спрямованість діяльності держави. Держава відповідає перед людиною за свою діяльність. Утвердження і забезпечення прав і свобод людини є головним обов'язком держави» [1]. Права людини декларовані величезною кількістю міжнародних актів, що передбачають людську гідність як особливу суспільну цінність, та покликані відстоювати захист людей у цілому світі. Людина завжди прагнула бути вільною та незалежною та історично боролася за дотримання свого права на життя, свободу та рівність за для найкращих умов існування, що стали початком зародження найважливішого досягнення людства - прав людини.

Первинні згадки про «права людини» мають довгу історію та сягають часів античності, де вже тоді людина та іiі життя, мали певну правову вагу та декларувалася рівність усіх перед божественними вищими силами. Зокрема, дані трактування були притаманні поглядам мислителів Стародавньої Греції.

В кінці II тис. до н.е. вже існувало таке поняття як закон - «номос». Також у даний історичний період оперували такими поняттями як «особиста честь», «справедливість» та «правда», що показує неабиякий розвиток права того періоду. У VI-V ст. до н.е. почали з'являтись ідеї щодо справедливості та моралі, які активно продокувалися піфагорійцями, котрі вважали, що жителі полісу повинні сповідувати мирне життя та моральність у взаємовідносинах між громадянами. Так, за вченнями Геракліта космічний порядок повинен відображатися у полісах, а космос є світовим порядком та особливої уваги приділяв справедливості. «Геракліт вважав, що цим началом є логос, тобто божественний світовий порядок, що досягає ідеалу. Він здіийснює керівництво Богами i людьми, саме божественний логос визначає божественну справедливість, оскільки «для Бога все $\epsilon$ справедливим, прекрасним i добрим, тоді як люди одне вважають справедливим, а інше несправедливим» [2, с. 156].

Давньогрецький філософ-матеріаліст Демокріт (V-IV ст. до н. е.) відстоював ідею світової закономірності у всіх їі проявах та вважав, що нічого без причинно неї не відбувається, тому один 3 небагатьох тогочасних мислителів не підтримував теорію божественного начала та відкидав ідею щодо надприродного. Він вважав, що держава $є$ наслідком життя соціуму та $є$ дечим «штучним». Демокріт наголошував на важливості свободи як першооснові та вважав, що свобода в бідності $\epsilon$ набагато кращою ніж рабство в багатстві. Таким чином, це були одні із перших прикладів філософії свободи, що з еволюційним періодом становлення права стала основою юридичної ідеології та прав людини.

Цінність людини та іï рівності була висловлена софістами в V-IV ст. до н. е., які також не 
традиційно для того періоду відкинули божественну теорію, а людину поставили як центр людського буття, пояснюючи світові феномени, тим самим змінивши підходи у натурфілософії. У даний період розвивалася ідея рівноправності людей, жителів тодішнього полісу. Найвідоміший філософ серед софістів вважається Протагор (481-411 р. до н. е.). Для нього «людина є мірою всіх речей», тобто мотивував, що саме людина є основою та найважливішим створінням на землі: «дари Прометея (вміння поводитися з вогнем та інші практичні знання) і дари Зевса («сором і правда», вміння спільно жити) були дані всім людям (еллінам), та що всім їм однаково доступне мистецтво полісного життя, $\mathrm{i}$ всі вони є громадянами полісу» [3. с. 266].

Софісти у своїх вченнях сповідували рівність людей як основу світобуття, тому вони розмежовували рабів чи варварів, пояснюючи це тим, що у всіх природньо закладено єдині природні потреби. А нерівність між людьми є результатом штучно створених людиною законів, що умисно ставить людей не в рівні становища, тому такі приписи мають «ворожий» характер для людини. Також неабиякого значення людині надавав послідовник софістів Алкід, наголошуючи на волі та рівності всіх людей, незалежно від походження, включаючи рабів.

Софісти розглядали людину як джерело природного права та, що саме від людини походить право, бо воно притаманне їй від народження. Протагор пише, що «люди, в різний час сприймають по-різному, в залежності від відмінності своїх станів. А саме той, хто живе за природою, сприймає те із існуючого в матерії, що може явитися як таке, що живе за природою, те ж, що живе протиприродно - те, що може являтися як таке, що живе протиприродно» [4, с. 66].

Природне право софісти трактували досить по-різному розділившись на дві основні течії. Спільним міркуванням було саме людська природа. Представники егалітаристської течії притримувались думки, що всі люди є рівні, незважаючи на місце народження, сім'ї чи статків. Тим самим переконуючи у людській рівності та необхідності у взаємоповазі кожної людини незалежно від походження, адже всі ми природньо наділені цими правами. Наголошувалось на необхідності у людському взаєморозумінні та підтримці кожного члена суспільства, що виключало таке явище як насильство - були основною ідеєю даної течії, як тлумачення природнього права.

Тоді як антиегалітаристська течія висвітлювала міркування, що хоч природне право $є$ рівне для усіх, попри те зароджує певну нерівність. Пояснюючи це природніми та індивідуальними відмінностями кожної людини.

Отже, софісти одні із перших давньо-грецьких філософів та мислителів розглядають не природу та космос як основу основ, а саме людину, яку наділяли особливим та вищим значенням у світобудові. Можливо також констатувати, що дані роздуми софістів стали наріжним каменем у зародженні ідей природного права як такого. Тим самим відійшовши від загальноприйнятого сприйняття буття у стародавні часи та заклали розвиток поняття рівності, справедливості та свободи, що і до сьогодні є найважливішими питаннями для цивілізованого світу та первинною засадою сучасних прав людини.

Не можливо також не згадати засновника західної філософії - Сократа. Оскільки, письмових праць даного мислителя так і не було знайдено, основні його ідеї були передані його учнями та послідовниками. Сократ вважав, що свобода $\epsilon$ неабияким надбанням для людини та підкреслював необхідність у дотриманні законів поліса для збереження даної рівноваги. Ідеї рівності прав та свобод людини були в подальшому розвинуті учнями Сократа, зокрема Платоном. Він вважав, що чоловіки i жінки мають природнє походження та однакову сутність, але і не відхиляв відмінність жіночої можливості до репродукції, що є особливістю саме жінок. Ідея рівності жінки була прогресивною, оскільки вона займала занижену соціальну роль та вважалася чимось середнім між твариною та чоловіком.

За філософією Платона в державі повинна панувати справедливість, враховуючи природні відмінності та нерівності людей. Мислитель розділяв людей за їхніми особливостями, та вважав, що у державі кожен повинен займати своє місце, іншими словами грати свою роль. Він виділяв філософів, мудреців «людей із розумною душею та наділені особливою мудрістю та відводив їм особливе місце у соціобутті»; воїнів «людей із навіженою душею та особливою відважністю», землеробів і ремісників «за своєю природою є розважливі та помірні». За Платонівською філософією кожна людина може перейти у інший статус, якщо досягне тих чеснот які притаманні цим соціальним станам, тобто досягне відповідної мудрості у своєму житті.

Аристотель (384-322 рр. до. н.е.) один із найвідоміших давньогрецьких мислителів та філософів. Він вважав, що політична справедливість і є відображенням права між рівними та вільними людьми та $є$ певним інструментом для таких взаємовідносин. Філософ підкреслював ідею справедливого закону, що виражався у політичному праві. I наголошував на неприйнятності 
владарювання поза правом чи у спосіб його порушення, визначаючи це як насильницьке підпорядкування, що суперечить основному праву та справедливості. Загалом Аристотель розподіляв справедливість за двома її видами: розподільну та зрівняльну.

Розподільна справедливість за твердженнями філософа, виражалась у справедливому розподілі цивілізаційних благ, таких як привілеї, влада та матеріальні блага, що вимірювалась згідно iз особистим внеском кожного окремого члена суспільства враховуючи їхню гідність для оцінки їхнього місця у тогочасному соціальному бутті. А зрівняльну справедливість філософ описує як справедливість, що застосовується за допомогою «арифметичного елементу», що притаманна у побутовому існуванні людини у випадках відшкодування завданих збитків особі чи застосування покарання для винного.

Аристотель вважав, що держава покликана забезпечити людині основні блага та життєві потреби. Основоположні ідеї, мислителя щодо забезпечення людини правами є підвалинами становлення прав людини у даному історичному періоді. Захист права власності та особистої недоторканості право на сім'ю, певна рівність між статями є гуманістичним підходом до побудови та сприйняття людини як цінності. Захист людини від злочинних діянь та відновлення справедливості за допомогою покарання винного та відшкодування шкоди за завдані збитки, вражають нас чіткістю та виразністю.

Згідно із твердженням філософа людина самостійно визначає свою поведінку, а держава повинна своїми силами сприяти такій позитивній поведінці як доброчесність. Аристотель вважав, що людина $\epsilon$ «соціальною істотою» та повинна жити в соціумі, таким чином підкреслював важливість громадянства як запоруку належного життя людини. Адже держава і «закони» створені та існують на благо людини та є найкращим проявом існування самої людини. Також закладаючи основні ідеї природніх прав людини, мислитель вважав, що нічого не існує абсолютного, сталого та все змінюється, як і сама людина.

Аристотель особливу уваги приділяв місцю сім’ї у державі та вважав, що сім’я є первинним осередком для людини та наголошував на необхідності належного виховання молоді як запоруки міцного суспільства та сильної, могутньої держави. Отже, необхідно правильно навчати молодих людей які були б наділені чеснотами та доброчесністю, були освіченими та культурними, вміли жити помірковано та були гідними громадянами. Мислитель розглядав людину як управителя державних справ, що була притаманна громадянам полісу та які були наділені політичними правами. «В основі будь-якого політичного устрою лежить відповідне поняття громадянина, сам Аристотель визначає громадянина як того, хто приймає участь у суді та управлінні, називаючи це абсолютним поняттям громадянина» [5].

Статус громадянства надавав людині особливого значення та можливість займати певне місце у тодішній ієрархії полісного життя, брати участь у народних зібраннях, які власне і здійснювались для управління справами полісу. Аристотель надавав особливого значення свободі та рівності громадян полісу. Громадяни брали активну участь у суспільному житті та обговорювали усі важливі питання, задля щасливого життя. Також філософ відстоював думку щодо важливості приватної власності людини та їі захисту.

Підсумовуючи, можна дійти до висновку, що основні трактати Аристотеля стали розвивати поняття громадянства та політичної участі людини у веденні громадських справ, що з еволюційними процесами стали основою першого покоління прав людини. Також розуміння та сприйняття Аристотелем важливості дотримання закону та верховенства справедливості мав на той час ключовий вплив на формування античного розуміння та сприйняття прав людини, закладаючи такі основні принципи, як рівність та свобода.

Висновки і перспективи подальших досліджень. Первинними формуваннями основних підвалин поняття прав людини сягають античних часів. Дане поняття було тісно пов'язане із громадянством, що існувало у Стародавній Греції та виявлялось у процесі становлення рівності жителів полісу та у можливості користуватися політичними правами. На основі доктринальних підходів Демокріта здійснилась поступова зміна теологічної парадигми буття, а центром стала людина іiі права та свободи. Вчення софістів удосконалили людиноцентриський підхід до прав людини, основою якої була рівність, що стала ідейним началом зародження природного права. На основі філософської думки Платона відбувся перший етап розвитку ідеї гендерної рівності. Аристотель своїми ученнями започаткував становлення принципу верховенства права та наділяв державу особливим регулятором, що здатний забезпечити права людей. Отже, античність відзначається як першим етапом зародження прав людини через тлумачення найвизначніших постатей даного періоду які закладали наріжні камені в історичній побудові даного поняття. 
Перспективою подальшого дослідження є наступні історичні періоди та етапи, що стали основними для зародження та розвитку інституту прав людини.

\section{Джерела та література}

1. Конституція України від 28 червня 1996 р. // Відомості Верховної Ради України. - 1996. - № 30. Ст. 141.

2. Дробышевский С. А. История политических и правовых учений: основные классические идеи: учеб. пособие / С. А. Дробышевский. - 2-е изд., доп. - Москва.: Норма, 2007. - 591 с.

3. Сігріянська В. С. До питання про права людини: генезис тлумачень та уявлень / В. С. Сігріянська // Альманах права. - 2017. - №8. - С. 264-269.

4. Антологія мировой философии: методический сборник философских текстов. Т. 1 / [сост.: М. А. Парнюк, В. И. Даниленко]. - Київ: УМК ВО, 1991. - 292 с.

5. Жаровська I. М. Генезис ідеї відкритості влади / І. Жаровська // Форум права. - 2009. - № 3. C. 242-246.

Турянский Ю. Генезис прав человека в период античности. В статье рассматривается историческая парадигма зарождения основ современного понимания прав человека в период античности. Исследовано историческое становление прав человека в древней Греции. В частности проанализированы основные мировоззренческие идеи Демокрита, Протагора, Сократа и Аристотеля. Первичное формирование основных принципов понятие прав человека достигает античных времен. Это понятие было тесно связано с гражданством в городах Древней Греции и проявлялось в процессе становления равенства жителей полиса и в возможности пользоваться политическими правами. Софисты одни из первых древнегреческих философов и мыслителей рассматривают не природу и космос как основу основ, а именно человека, которого наделяли особым и высшим значением в мироздании. Естественное право софисты трактовали весьма различно, разделившись на два основных течения. Общим соображением было именно признание человеческой природы как источника права. Представители эгалитаристского течения придерживались мнения, что все люди равны, несмотря на место рождения, семью или имущественные доходы. На основе философской мысли Платона основан первый этап развития идеи гендерного равенства. По философии Платона в государстве должна господствовать справедливость, учитывая природные различия и неравенства людей. Мыслитель разделял людей по их особенностям и считал, что в государстве каждый должен занимать свое место. Аристотель своим учением начал становление принципа верховенства права и рассматривал государство как особый регулятор, который способен обеспечить права людей. Поэтому античность оценивается как первый этап зарождения прав человека. Выдающиеся личности того периода через философское толкование заложили краеугольные камни в историческом развитии данного понятия. Основные трактаты Аристотеля стали развивать понятие гражданства и политического участия человека в ведении общественных дел, связанных с эволюционными процессами стали основой первого поколения прав человека.

Ключевые слова: права человека, государство, общество, права, свободы.

Turiansky Yu. Human Rights Genesis in the Times of Antiquity. The article deals with the historical paradigm of the origin and development of the modern understanding of human rights since the times of antiquity. The historical aspect of the formation of human rights in Ancient Greece, in particular, the basic philosophical ideas of such philosophers as Democritus, Protagoras, Socrates, and Aristotle, are in the focus of the study. The development of the foundations of the human rights concept dates back to the ancient times. This concept was closely related to citizenship existing in ancient Greece and manifested itself in the process of introducing equality among the residents of the city-state (police) and providing them with a possibility to enjoy political rights. Sophists, one of the first ancient Greek philosophers and thinkers, do not consider nature and space as the basis of foundations, but person, who was given a special and higher importance in the universe. Sophists were divided into two main currents, whch interpreted natural law quite differently. The common thought was human nature. The egalitarian movement held that all people were equal, regardless of place of birth, family, or wealth. The ideas of gender equality developed on the basis of Plato's philosophical thought. It was the first stage. According to Plato's philosophy, justice must prevail in the state, taking into considerationt he natural differences and inequalities of the people. The thinker divided people according to their characteristics, and believed that everyone should take their place in the state. Aristotle, in his teachings, established the principle of the rule of law and granted the state a special function 
of regulator, able to ensure the rights of the people. Therefore, we can regard antiquity as the first stage of the emergence of human rights. Through the interpretation of the prominent figures of that period, they laid the cornerstones in the historical construction of the concept. Aristotle's main treatises began to develop the concepts of citizenship and political participation in public affairs, which with evolutionary processes became the basis of the first generation of human rights.

Key words: human rights, state, society, rights and freedoms.

УДК $340.12: 327.39$

DOI https://doi.org/10.32782/2409-4544/2019-2/8

М. Щирба

\section{Розуміння права на здоров'я у Цілях сталого розвитку}

У статті проаналізовано положення глобальних Цілей сталого розвитку, які були затверджені у 2015 р. на Саміті ООН зі сталого розвитку. Вони вказують на тенденції розвитку прав людини i визначають основні завдання цивілізованих народів, які повинні бути досягнуті до 2030 року. Здоров'я людини визначається комплексом біологічних (спадкових і набутих) та соціальних факторів. Доведено, що Мета 3 «Забезпечення здорового життя» прирівнюється до права на медичні послуги важливе саме по собі через мету, яка $є$ практичним засобом досягнення поставленого завдання. Також право на охорону здоров'я має стосуватися не лише медичних послуг, а й соціальних та економічних детермінант стану здоров'я. Право на охорону здоров'я включає дві вагомі методологічні складові: не лише право на доступ до медичних послуг, але і соціальні і економічні детермінанти стану здоров'я людини. Аргументовано, що міжнародне співтовариство пріоритетно акцентує увагу виключно на тих елементах, які визначені в Цілі 3, при цьому не допускає широкого тлумачення завдань в сфері охорони здоров'я. Найбільшу увагу в тексті рекомендацій приділено гендерному насильству, здоров'ю матері і дитини, соціально-економічним детерминантам здоров'я, а також системі охорони здоров'я і надання медичних послуг. У той же час питання здоров'я окремих категорій населення (підлітків, представників національних меншин, людей 3 обмеженими можливостями) розкриті досить фрагментарно. Також не всі теми охорони здоров'я отримали однаковий ступінь висвітлення в рекомендаціях ООН. Так, в рекомендаціях достатньо поверхнево висвітлено піходи до профілактики та лікування психічного здоров'я та неінфекційних захворювань.

Ключові слова: право людини, охорона здоров'я, право на здоров'я, медичні послуги, Цілі сталого розвитку.

Постановка наукової проблеми та ії значення. Сучасний світ увійшов в нову епоху правового регулювання інституту прав людини. Для того, щоб зрозуміти сутність прав людини й вказати на тенденції їх розвитку та правового закріплення, на рівні міжнародного погодження були прийняті Глобальні Цілі сталого розвитку (далі - ЦСР), які були затверджені у 2015 році на саміті $\mathrm{OOH}$ з питань сталого розвитку. Перше, що слід зазначити, це те, що «Трансформація нашого світу: порядок денний сталого розвитку до 2030 р.» - резолюція, прийнята Генеральною Асамблеєю ООН, в якій були визначені ЦСР, містить значну кількість прав. Дійсно, в Преамбулі зазначалося, що однією з ключових цілей ЦСР $є$ «реалізація прав усіх людей». Застосовувалися міжнародні документи 3 прав людини, включаючи Загальну декларацію прав людини (пп. 10, 19) та конкретно зазначалося «право на розвиток» (параграфи 10, 35).

Більшість держав світу прийняла цей міжнародний акт в якості державницького напряму розвитку всіх сфер народного господарства. Україна також долучилася до цього процесу, за ініціативи Уряду України та за сприяння інституцій ООН в Україні протягом року тривав відкритий та інклюзивний процес адаптації ЦСР.

Означені цілі включають значну кількість складових, в межах цієї статті акцентуємо увагу на розумінні права на здоров’я у вищезазначеному документі як цінності для народу, держави, особи та майбутніх поколінь.

Аналіз досліджень проблеми. Останнім часом значно зріс інтерес науковців до проблем

() Щирба М., 2019 